\title{
Synaptonemal Complex Protein 1
}

National Cancer Institute

\section{Source}

National Cancer Institute. Synaptonemal Complex Protein 1. NCI Thesaurus. Code C114400.

Synaptonemal complex protein 1 (976 aa, $\sim 114 \mathrm{kDa}$ ) is encoded by the human SYCP1 gene. This protein plays a role in the structure of the synaptonemal complex during meiotic prophase. 